\title{
Testimonio del Señor Elie Alevi, en homenaje a Raoul Wallenberg ${ }^{1}$ Homage to Raoul Wallenberg, Testimony of Mr. Elie Alevi,
}

Señoras y Señores, Me asignaron poco tiempo para dar mi testimonio como sobreviviente del holocausto. Por este motivo, preferí escribirlo y leerlo, en un relato corto, ordenado y condensado.

Muy merecido el homenaje al diplomático sueco, Raoul Wallenberg.

No cabe duda, él fue uno de los pocos hombres buenos y justos, de la cruel y deshumanizada Segunda Guerra Mundial, en la que muchos millones de seres humanos, sufrieron lo indecible y murieron en las peores condiciones. Entre ellos, 6 millones de correligionarios, de religión judía.

Por este motivo, la Embajada de Israel me pidió que diera mi testimonio, como sobreviviente del holocausto y como víctima de los infernales campos de exterminio de AuschwitzBirkenau, donde murieron también, todos los miembros de mi familia.

Durante los 20 primeros años, desde mi liberación, no pude hablar del tema. La intensidad de las emociones no me permitía poner en palabras el sufrimiento y los horrores vividos.

Por otro lado, tampoco creía que fuera posible que alguien creyera, que una nación de gran cultura, como era Alemania en esa época, hubiera permitido que el partido nazi ideara y ejecutara este genocidio. Pero, es cierto, en dictadura se pierden todas las libertades y sobre todo la de expresión y protesta.

Por este motivo, yo perdoné al pueblo alemán y no guardo rencor ni resentimiento.

\footnotetext{
${ }^{1}$ Este Testimonio fue presentado por el sr. Alevi en la sede de Cepal en Santiago, en el Acto de recordación de Raoul Wallenberg. 
Sin embargo, este brutal, cruel e inhumano genocidio no debiera ni podrá olvidarse jamás, para que nunca, nunca más vuelva a repetirse. Increíblemente, esto sucedió en pleno siglo 20 y no en la edad de piedra.

No me extenderé mucho más sobre el holocausto. Todos han leído y visto películas y videos, en los que tratan de describir el infierno de los campos de exterminio nazis. Sin embargo, créanme, quedan cortos, no se puede expresar en palabras e imágenes la minuciosa organización que se usó para lograr exterminar tanta gente, en tan poco tiempo.

Ahora les contaré, brevemente, lo que pasó en Tesaloniki (Grecia), mi ciudad natal, donde 50.000 judíos griegos, vivíamos una vida apacible y tranquila: Yo tenía 14 años cuando las tropas nazis invadieron Grecia en 1941.

Una semana después de la invasión, se instaló la Gestapo, iniciando sin demora la persecución a la población de religión judía: Empezaron enviando a trabajos forzados a muchos jóvenes de 21 a 45 años. No se sabe donde perecieron.

Después, nos obligaron a llevar la estrella de David en las solapas de nuestra vestimenta, y también, poner la estrella en las vitrinas de los negocios con la inscripción "negocio judío, evite comprar".

Luego, nos encerraron en pequeños guetos, apiñando 4 familias por departamento. Dentro del gueto, nos impusieron terribles restricciones, (500 calorías al día por persona) y en servicios domiciliarios, (2 horas de agua y luz al día).

Durante este período, murió mucha gente por inanición, enfermedades y falta total de medicamentos.

También, a cualquier hora del día, entraban en nuestros domicilios, para robar y violar, usando tratos crueles y vejatorios. 
Finalmente, en marzo de 1943, llegó el día fatídico de nuestra deportación. De madrugada, a las 5 de la mañana, invadieron nuestro gueto de 2.500 personas. Nos obligaron a preparar en 20 minutos una pequeña maleta por persona. Recalcaban insistentemente: lleven solamente los objetos de valor.

No se preocupen, lo demás se les proporcionará gratuitamente en vuestro destino.

\section{¡i QUE CRUEL IRONÍA !!}

En filas de 5 personas nos dirigieron a pie a la estación de trenes, ahí nos esperaban los vagones de ganado. Nos apiñaron 60 personas en cada vagón, y, en el Interior, encontramos dos barriles uno con agua y otro vacío para los excrementos. Lo que pasó durante los 5 días que duró el trayecto, es indescriptible e inimaginable.

Fue terrible escuchar los gritos y llanto de los niños, los gemidos y quejidos de los ancianos y enfermos, y aguantar el olor nauseabundo del ambiente. Cuando caíamos de cansancio y de sueño, dormíamos uno encima de otro por falta de espacio.

Este martirio fue inaguantable para los enfermos y bebés, muchos de ellos murieron en el trayecto. Todos los días por las mañanas, los guardias evacuaban los cadáveres.

A las 5 de la mañana del $6^{\circ}$ día, unos potentes reflectores se encendieron iluminando los vagones y las puertas se abrieron de par en par. Los guardias, acompañados de perros, subieron y nos tiraron fuera de los vagones. Amontonaron las maletas delante de cada vagón. Nunca más las volveríamos a ver.

Estando todos en tierra, empezó de inmediato la selección: Ancianos y niños en una filla. En las otras dos filas y separados, hombres y mujeres jóvenes y aptos para trabajar. Los ancianos y niños fueron evacuados inmediatamente en camiones y, llevados a las cámaras de gas y a los hornos crematorios. A las otras dos filas nos encaminaron a pie a los campos respectivos. 
Dentro del campo, nos dirigieron a un barracón, donde nos desnudaron, desinfectaron, raparon y tatuaron un número en el brazo. A partir de este momento nos identificaban por el número. Yo era el 120.693.

Luego nos entregaron la ropa listada, un par de zuecos y dos trapos como calcetines.

De ahí, nos enviaron a los barracones asignados. A mí me tocó-sólo-, en un barracón donde quedaba una sola plaza vacía, cuyo ocupante había muerto el día anterior. En Birkenau, no se desperdiciaba ninguna plaza. Diariamente llegaban nuevos contingentes de deportados de todos los países ocupados.

En este barracón todos hablaban idiomas, que yo no entendía. Yo, solamente hablaba el griego. Ninguna comunicación fue posible con los demás para saber por el resto de la familia. Finalmente, alguien se compadeció de mí, me llevó a la puerta y con el dedo me mostró el humo que salía de las chimeneas, queriéndome decir: ahí están tus padres.

Al día siguiente, en el trabajo me asignaron un capo, tan sanguinario como el jefe de mi barracón. Ellos, tenían el poder de vida o muerte sobre cada uno de nosotros. El capo vigilaba nuestro trabajo en las canteras. Mi rabajo consistía en transportar con carretilla, piedras, para la construcción de caminos.

La alimentación en el campo era como para exterminarnos. Así, dejaban espacio para los nuevos contingentes. A las 6 de la mañana nos daban un café de cebada, 200 granos de pan duro y 12 gramos de margarina. Al almuerzo y cena una sopa de rábanos y cáscara de papas. Los primeros dos días, no pude tragar mis raciones de comida. Mis compañeros de miseria, felices, me las arrebataban.

No voy a seguir con mi relato en Auschwitz-Birkenau, solo quise darles una pequeña muestra, del infierno que fue aquello. 
Después de 5 meses en Birkenau, aún con algo de fuerzas, tuve la suerte de ser trasladado al campo de trabajo del gueto de Varsovia, donde me asignaron a las cocinas de los guardias. Lavando las ollas, cuchareaba los restos de comida.

Gracias a esto, pude alimentarme mejor durante los 11 meses siguientes y después, aguantar la tristemente famosa "MARCHA DE A MUERTE" entre Varsovia y Dachau.

El recorrido era de 1200 kilómetros y de 30 días de duración. El alimento fue poquísimo y el agua casi nula. Hoy, aún, cuando bebo agua, recuerdo el calvario que significó la falta de líquido, tan vital para la vida. En esta marcha, murieron más de 1.800 compañeros de campo.

Unos meses después, fui liberado en Dachau, por los americanos, el 5 de mayo de 1945.

Ustedes se preguntarán ¿Cómo pude rehacer mi vida? Fue gracias a un pariente mayor que vivía en Paris, casado con francesa y que lo salvo a él de la deportación. Me invitaron a Francia, a integrarme a su familia, dándome afecto, cariño y apoyo económico para retomar mis estudios y graduarme en ingeniería, en la ciudad de Lyon.

Por todos los tremendos sufrimientos padecidos durante el holocausto, se comprende mucho mejor, lo que significó la labor de RAOUL WALLENBERG, quien, arriesgando constantemente su vida, salvó a miles de judíos húngaros del infierno y de la muerte.

\section{GRACIAS POR HABERME ESCUCHADO}

